\title{
Cytokine responses in pigs after natural infection with classical swine fever virus
}

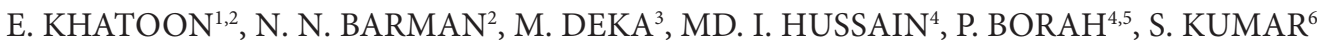

\begin{abstract}
${ }^{1}$ Department of Biotechnology, Gauhati University, Assam, India; ${ }^{2}$ Department of Microbiology, College of Veterinary Science, Khanapara, Assam, India; ${ }^{3}$ Department of Bioengineering and Technology, Institute of Science and Technology, Gauhati University, Assam, India; ${ }^{4}$ State Biotech Hub, College of Veterinary Science, Khanapara, Assam, India; ${ }^{5}$ Department of Animal Biotechnology, College of Veterinary Science, Khanapara, Assam, India; ${ }^{6}$ Department of Biosciences and Bioengineering, Indian Institute of
\end{abstract} Technology Guwahati, Guwahati, Assam, India

Received February 2, 2018; revised May 5, 2018; accepted January 7, 2019

\begin{abstract}
Summary. - Classical swine fever (CSF) is a highly contagious viral infection that affects domestic and wild pig population. The classical swine fever virus (CSFV) targets immune cells which perturb the immune functions causing immunopathological disorders such as immunosuppression, leukopenia and haemorrhage. In the present study, ELISA and quantitative real-time reverse transcription PCR (qRT-PCR) analysis was employed to determine cytokine profiles in pigs naturally infected with CSFV using whole blood assay (WBA) under field conditions. Significantly higher TNF- $\alpha$, IL-10, and IL- 6 expression levels were found in unvaccinated pigs infected with CSFV (group B) compared to vaccinated pigs that recovered after CSF (group A), the difference being statistically significant $(p=0.001)$. However, the expression of IFN- $\gamma$ was significantly higher in group A compared to group B $(\mathrm{p}=0.001)$. The findings of this field-supported study will help us to understand the immune biology of CSFV infection in infected pigs. The WBA technique can be used as a reliable, fast and feasible in vitro method to assess porcine cellular immune responses as it imitates the porcine blood conditions. Such studies could be of some value in determining the immune status of the ailing animals infected with CSFV.
\end{abstract}

Keywords: classical swine fever virus; immune response; field conditions; interleukin; IFN- $\gamma$; TNF- $\alpha$

\section{Introduction}

Classical swine fever (CSF) is an OIE (Office International for Epizooties) notifiable, highly contagious viral disease of domestic pigs and wild boars. It is an economically important trans-boundary endemic disease of Asia, Central and South America, some parts of Europe, and Africa (Arzt et al., 2010). Pathological changes in acute infection are often observed in the lymph nodes, spleen and kidneys (Paton and Greiser-Wilke, 2003). Swollen lymph nodes, haemorrhages in the kidney, infarctions of the spleen, atrophy of the thymus

E-mail: elinakhatoon@gmail.com; phone: +91-8638057761.

Abbreviations: $\mathrm{CSF}=$ classical swine fever; $\mathrm{CSFV}=\mathrm{CSF}$ virus; $\mathrm{IF}$ = interferon; IL = interleukin; qRT-PCR = quantitative realtime reverse transcription PCR; TNF = tumor necrosis factor; $\mathrm{WBA}=$ whole blood assay and depletion of the lymphocytes from germinal follicles are considered to be pathognomonic for CSFV infection (Sato et al., 2000). CSF is a viral haemorrhagic disease that mainly infects macrophages and monocytes. Macrophages sustain in vivo replication of CSFV during acute phase of its infection (de las Mulas et al., 1997; Narita et al., 2000). Vaccination is the major way to protect the animals against CSFV infection. However, inappropriate vaccination and faulty management practices could lead to frequent outbreaks of CSFV in the pig herds (Sarma and Sarma, 1998; Rahman et al., 2001; Barman et al., 2003, 2010; Suradhat and Damrongwatanapokin, 2003).

CSF is caused by classical swine fever virus (CSFV). The etiological agent, CSFV, is a member of the genus Pestivirus (the family Flaviviridae) and is closely related both antigenically and structurally to the bovine viral diarrhoea virus (BVDV) and border disease virus (BDV) (Francki et al., 1991). 
The CSFV is an icosahedral enveloped virus, which contains positive sense RNA as a genetic material. The RNA carries a single large open reading frame (ORF) which encodes a large polyprotein that is co- and post-translationally cleaved into the 12 proteins Npro, C, Erns, E1, E2, p7, NS2, NS3, NS4A, NS4B, NS5A, and NS5B by cellular and viral proteases.

CSFV is a major issue for the pig farmers in India. CSFV is endemic mainly in North eastern part of India and frequent outbreaks have been reported in the recent years (Sarma and Sarma, 1998; Barman et al., 2003; Sarma et al., 2008, 2011). Despite the knowledge available, many aspects of classical swine fever immunopathogenesis are still puzzling. Wild virulent virus makes every effort to evade host defence barrier by down regulating immune response while, attenuated vaccine virus evokes protective immune response. In both immuno-regulatory mechanisms, various cytokines play crucial roles and, thus, cytokines can serve as markers for ongoing infections and can be valuable tools in herd health monitoring programs.

A better knowledge of immunological aspects is necessary in order to understand the efficacy of vaccine and vaccination strategy against CSFV infection. Neutralizing antibodies in pig usually appear about two weeks post-vaccination (Renson et al., 2013). Although there is correlation between the induction of neutralizing antibodies by vaccination and protection against CSFV (Terpstra and Wensvoort, 1988; Ganges et al., 2008), several studies suggested the involvement of other immune mechanisms, such as cellular responses against CSF antigens, that confer protection in the absence of detectable anti-CSFV antibodies (Rumenapf et al., 1991; Hulst et al., 1993; Suradhat et al., 2001; Ganges et al., 2005).

The characteristic of CSF is the marked immuno-suppression elicited on infected animals, together with the depletion of B-lymphocytes and T-lymphocytes (Li et al., 2009). CSFV exhibits efficient viral strategies to escape the type I interferon (IFN)-induced antiviral mechanisms, thereby, efficiently evading and compromising the host immune system. IFN expression induced by extracellular viral RNA is inhibited by the viral RNase Erns, in addition, the viral protein Npro suppresses type I IFN (IFN- $\alpha / \beta)$ induction by mediating proteasomal degradation of IFN regulatory factor 3 (IRF-3) (Muñoz-González et al., 2016). It is well established that macrophages and $\mathrm{T}$ lymphocytes associated cytokines and chemokines play an important role in maintaining the antiviral immune response (Abbas et al., 1996). CD8 ${ }^{+} \mathrm{T}$ cells are cytotoxic for CSFV and increase in their range throughout the infection, might be a part of host defence reaction (Doherty et al., 1992; Pauly et al., 1995; Summerfield et al., 1996).

The current study was intended to evaluate the differential expression pattern of TNF- $\alpha$, IL-6, IFN- $\gamma$ and IL-10 during CSF infection. CSFV infection is characterized by the enhanced release of IFN- $\alpha$ and proinflammatory cytokines, such as TNF- $\alpha$, IL- 6 and IL-1, which disturb the homeostasis of the cellular environment (Jamin et al., 2008). TNF- $a$ has been shown to induce apoptosis in different cell populations (Zheng et al., 1995) and TNF-a released during systemic viral infection is potentially a mediator for the induction of apoptosis in the lymphoid tissues. TNF- $\alpha$ and IL- 6 are assumed to participate in the formation of haemorrhages, characteristic of the acute form of CSF disease (SanchezCordon et al., 2005a). Previous studies have shown that the C-strain vaccine induces IFN- $\gamma$ production postvaccination (Suradhat et al., 2001; Graham et al., 2012) which served as a good marker for anti-CSFV cell mediated responses. During CSFV infection, IL-10 facilitates immunosuppression and viral persistence by inhibiting the activity of Th1 and NK cells (Blackburn and Wherry, 2007; Couper et al., 2008). The C-strain virus is a potent inducer of a type- $1 \mathrm{~T}$ cell response, which may play a role in the protection afforded by such vaccines, whereas the proinflammatory cytokine responses observed in infected pigs may reflect a pathological pro-inflammatory cascade initiated following the replication and spread of CSFV.

There is paucity of information on various cytokine responses upon CSFV infection in pigs, moreover, the role of various cytokines in elimination and pathological process of the virus is poorly understood. Various studies focused on the analysis of porcine cytokine expression either in specific pathogen free animals experimentally infected with CSFV or in vitro cell-culture system (Pauly et al., 1995; Summerfield et al. 1996, 2001; Suradhat et al., 2001, 2005; Sanchez-Cordon et al., 2005, 2005a; Borca et al. 2008; Graham et al., 2009, 2012; Renson et al., 2013). Field-supported studies could aid the overall understanding of cytokine profiles that will facilitate in elucidating the contribution of various cytokines in protective immunity and also could help in improving the development and delivery of protective vaccines.

In the present study, we have determined cytokine gene expression in pigs naturally infected with CSFV using whole blood assay (WBA). Generally, for such purpose in vitro stimulation of whole blood or isolated peripheral blood cells with specific antigens is employed. However, because of their paracrine and autocrine nature, most cytokines are found at very low levels in peripheral blood. To overcome this problem, in vitro stimulated cells are used in order to achieve the correct time point for a cytokine's peak value. However, several studies have explored cytokine dynamics and investigators found that the optimal time point for measuring a particular cytokine is influenced by dissimilarities between techniques (Lagrelius et al., 2006). Kinetic patterns of various cytokines are affected by complex factors, moreover, PBMC (peripheral blood mononuclear cell) separation procedures e.g., Ficoll or lymphoprep density gradient centrifugation techniques are toxic, harmful to certain cell populations, and therefore, PBMC cultures might have lower cell viability than whole blood (Kuleshova et al., 2001). So, 
to assess factors related to the porcine immunological response to CSFV, such as cytokine production, WBA might better preserve cell viability. The WBA has several additional advantages: it uses a smaller sample volume (approximately 1-2 ml), consumes less time (approx. $15 \mathrm{~min}$ ), requires less laboratory equipment and is cheaper. Moreover, as cellular and non-cellular components e.g. plasma and granulocytes are preserved, it maintains a more physiologic environment (Silberer et al., 2008).

A quantitative PCR assay and ELISA was used to quantify the interleukin (IL)-6, IL-10, interferon gamma (IFN- $\gamma$ ) and tumor necrosis factor alpha (TNF- $\alpha$ ) level in animals under study. It would be interesting to understand post-infection modulations in the cytokine response and their attenuation by vaccination, which would help in correlating the role of different cytokines in CSFV pathogeny and protection. Our results indicate that IFN $-\gamma$ mediated immune response might be a major entity in protecting pigs against CSFV infection. To the best of the authors' knowledge, this is the first report on the cytokine profile in pigs after natural infection with classical swine fever virus.

\section{Materials and Methods}

CSF vaccine. Vaccinated animals were injected intramuscularly (i.m.) with $1 \mathrm{ml}$ of the cell culture adapted C-strain of CSFV (containing $10^{3} \mathrm{TCID}_{50} / \mathrm{ml}$ ) one month prior to the CSF outbreak.

Grouping of animals. A herd of crossbreed pigs (Hampshire $\mathrm{x}$ local), aged 1-3 months were attended from an outbreak in the Kamrup district of Assam, India, between April-May 2014. The study was conducted on animals divided in three groups - A, B and C (Table 1). Group A (aged 2-3 months) comprised of 20 CSF infected animals that were vaccinated against CSF; all animals recovered after CSF infection and no mortality was recorded among the group A animals. Group B (aged $<2$ months) comprised of 20 CSFV infected animals having no history of vaccination against CSF; all animals in group B succumbed to CSF infection. Group C (aged $<2$ months) included unvaccinated apparently healthy group of piglets (20 numbers), maintained at organized private pig farms having no evidence of CSFV infection and were used as control. All animals were monitored for any concomitant infection other than CSFV. Approval for the research on animal was obtained from Institutional animal ethics committee, Gauhati University, Assam, India (Ref. No. IAEC/PER/2015-16/04).

Collection of samples. Blood samples were collected in the early phase of CSFV infection ( $<1$ week post infection).

Screening of samples for CSFV nucleic acid and pig anti-CSFV antibody. Viral RNA was extracted from whole blood using RNATRI reagent (Ambion, USA), following the manufacturer's instructions. Extracted RNAs were treated with DNase I and stored at $-20^{\circ} \mathrm{C}$ until further use. Presence of CSFV genome was confirmed by one-step TaqMan real-time PCR using viral gene specific primers with fluorescence probe as described earlier (Hoffmann et al., 2005). The primers and MGB (minor groove binding) probes tagged with 6-carboxyfluorescein (FAM) as the 5'-reporter dye were used for the qRT-PCR (Applied Biosystems, USA). Blood samples were collected from all the animals for serology and cytokine assay. For serum preparation, after collection of whole blood, the blood was allowed to clot by leaving it undisturbed at room temperature for 15-30 min. The clot was removed by centrifugation at 1,000-2,000 $\mathrm{x} g$ for $10 \mathrm{~min}$. in a refrigerated centrifuge and the resulting supernatant, designated serum, was carefully removed using a Pasteur pipette and stored in $4^{\circ} \mathrm{C}$ and processed for the assay within 24 hours of its collection. The antibody status of the animals included in the study was assayed by indirect ELISA (IDEXX, Switzerland) following manufacturer's instructions.

Measurement of cytokine concentration by ELISA. Cytokine concentration in plasma of all the groups under study were estimated by using commercial ELISA kits. RayBio Porcine ELISA kits (RayBiotech, USA) were used for measuring IL-6 (ELP-IL6), IFN- $\gamma$ (ELP-IFNg) and TNF- $\alpha$ (ELP-TNF $\alpha$ ), and Swine IL-10 ELISA kit (Invitrogen, USA) was used for measuring IL-10 (KSC0101) according to manufactures' instruction.

Relative quantification of cytokine expression using quantitative real-time reverse transcription $P C R$ ( $q R T-P C R)$. RNA was extracted from whole blood using RNA-TRI reagent (Ambion, USA), following the manufacturer's instructions. The DNase treated-RNA was quantified and equal amounts were taken from all the samples for reverse transcription. The obtained cDNA was used for gene expression quantification of porcine IL-6, IL-10, IFN- $\gamma$ and TNF- $\alpha$. The expression of $\beta$-actin gene was used as an endogenous control. The cDNA was amplified by qRT-PCR using Power SYBR ${ }^{\oplus}$ Green PCR master mix (Applied Biosystems, UK). Briefly, $20 \mu$ reaction

Table 1. Animals used in the study with their history and clinical details

\begin{tabular}{|c|c|c|c|c|c|}
\hline \multicolumn{2}{|c|}{ Groups/age/status } & \multirow{2}{*}{$\begin{array}{c}\begin{array}{c}\text { No. of animals } \\
\text { under study }\end{array} \\
20\end{array}$} & \multirow{2}{*}{$\begin{array}{c}\text { Vaccination status } \\
1 \text { month post } \\
\text { vaccination }\end{array}$} & \multirow{2}{*}{$\begin{array}{l}\text { Clinical status } \\
\text { tof onset of clinical } \\
\text { toms }\end{array}$} & \multirow{2}{*}{$\begin{array}{c}\begin{array}{c}\text { Follow-up health status } \\
\text { of the animal }\end{array} \\
\text { recovered after infection }\end{array}$} \\
\hline $\begin{array}{l}\text { Group A } \\
\text { (2-3 months) }\end{array}$ & vaccinated-infected & & & & \\
\hline $\begin{array}{l}\text { Group B } \\
(<2 \text { months })\end{array}$ & unvaccinated-infected & 20 & unvaccinated & $\begin{array}{l}7 \text { days of onset of clinical } \\
\text { symptoms }\end{array}$ & $\begin{array}{l}\text { all succumbed to CSF } \\
\text { infection }\end{array}$ \\
\hline $\begin{array}{l}\text { Group C } \\
(<2 \text { months })\end{array}$ & unvaccinated-uninfected & 20 & unvaccinated & $\begin{array}{l}\text { Uninfected/no history of } \\
\text { infection }\end{array}$ & all healthy \\
\hline
\end{tabular}


Table 2. Primer sets used in the study

\begin{tabular}{|c|c|c|c|c|}
\hline Gene & Primer sequence (5'-3') & Melting temperature & Amplicon size & Reference \\
\hline \multirow{2}{*}{ IL-6 } & CGGTCTTGTGGAGTTTCAGATA & \multirow{2}{*}{$77.5^{\circ} \mathrm{C}$} & \multirow{2}{*}{$106 \mathrm{bp}$} & \multirow{6}{*}{$\begin{array}{l}\text { designed } \\
\text { (IDT primer quest) }\end{array}$} \\
\hline & CTGGATCAGTGCTTTGGTACT & & & \\
\hline \multirow{2}{*}{ IFN- $\gamma$} & ACCTAAGAAAGCGGAAGAGAAG & \multirow{2}{*}{$74.1^{\circ} \mathrm{C}$} & \multirow{2}{*}{$83 \mathrm{bp}$} & \\
\hline & CAAATATTGCAGGCAGGATGAC & & & \\
\hline \multirow{2}{*}{ TNF- $\alpha$} & CCAATGGCAGAGTGGGTATG & \multirow{2}{*}{$82.7^{\circ} \mathrm{C}$} & \multirow{2}{*}{$114 \mathrm{bp}$} & \\
\hline & AAGAGGACCTGGGAGTAGATG & & & \\
\hline \multirow{2}{*}{ IL-10 } & CGGCGCTGTCATCAATTTCTG & \multirow{2}{*}{$79.9^{\circ} \mathrm{C}$} & \multirow{2}{*}{$89 \mathrm{bp}$} & \multirow{2}{*}{ Borca et al., 2008} \\
\hline & ССССТСТCTTGGAGCTTGCTA & & & \\
\hline \multirow{2}{*}{$\beta$-actin } & GACATCCGCAAGGACCTCTA & \multirow{2}{*}{$85.7^{\circ} \mathrm{C}$} & \multirow{2}{*}{$157 \mathrm{bp}$} & \multirow{2}{*}{ Galindo et al., 2012} \\
\hline & ACACGGAGTACTTGCGCTCT & & & \\
\hline
\end{tabular}

included $10 \mu \mathrm{l}$ of Power SYBR ${ }^{\star}$ Green PCR master mix, $3 \mu \mathrm{l}$ of cDNA, and $5 \mu \mathrm{M} / \mu \mathrm{l}$ of each primer. Cycling conditions included $95^{\circ} \mathrm{C}$ for $10 \mathrm{~min}$, followed by 40 cycles of reaction at $95^{\circ} \mathrm{C}$ for 15 $\mathrm{sec}$, and $60^{\circ} \mathrm{C}$ for $1 \mathrm{~min}$. Relative quantification (RQ) of mRNA expression was calculated by the $2^{-\Delta \Delta \mathrm{Ct}}$ method (Livak and Schmittgen, 2001). Cytokine gene expression of the group A and B were compared to that of the group $\mathrm{C}$ animals. The details of the primers are listed in Table 2.

Statistical analysis. The collected data were analyzed using SPSS version 13 software package (SPSS, Inc., USA). Results were expressed as means \pm standard deviations (SD). Statistical analyses were performed using Mann-Whitney nonparametric test. The $p$ values of less than 0.05 were considered significant throughout. The error bars on the graphs represent the SD.

\section{Results}

\section{Clinical symptoms of the infected pigs}

Clinical signs of inappetence, high fever and constipation were observed in the affected animals along with diarrhoea and haemorrhagic patches in the skin. All animals were monitored for any concomitant infection. All the animals

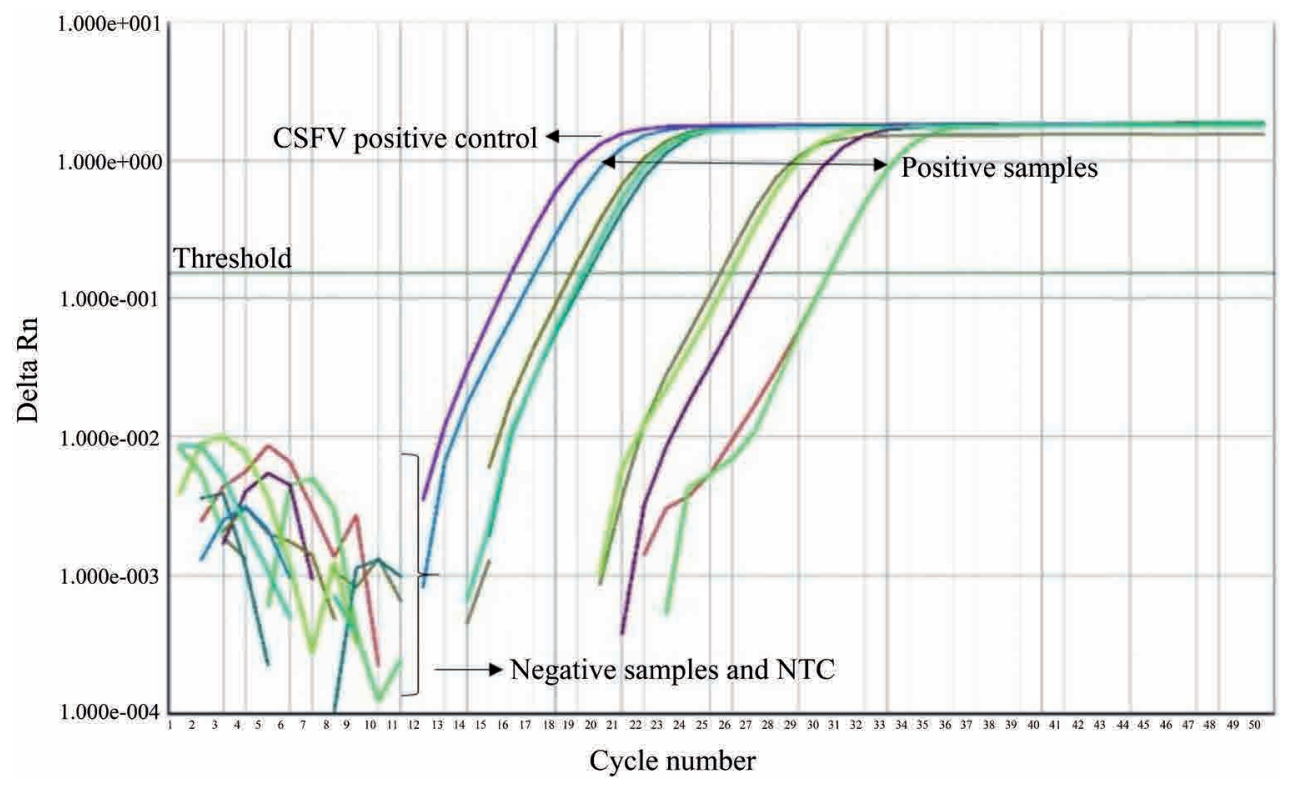

Fig. 1

Amplification plot showing the TaqMan qRT-PCR based detection of CSFV

Qualitative (positive/negative) responses were recorded; amplification curves that crossed the threshold $\Delta$ Rn value were considered positive while samples showing no Ct were considered as negative. 


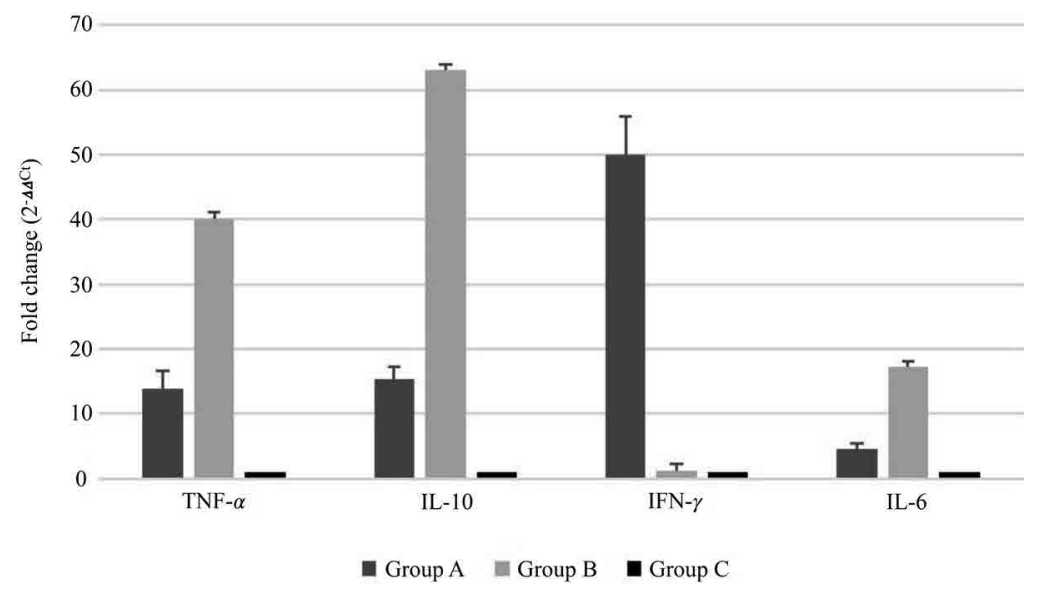

Fig. 2

Bar diagram representing the fold change $\left(\mathrm{RQ}=2^{-\Delta \Delta \mathrm{Ct}}\right)$ in TNF- $\alpha$, IL-10, IFN- $\boldsymbol{\gamma}$ and IL-6 gene

The gene expression was analyzed in group A (vaccinated-infected) and group B (unvaccinated-infected) relative to group C (healthy controls). All data were reported as the mean \pm SD of RQ results and the error bars represent the SD.

were found negative for porcine reproductive and respiratory syndrome virus and porcine circovirus infection.

\section{Screening of samples for CSFV nucleic acid}

Amplification curves that crossed the threshold $\Delta \mathrm{Rn}$ value were considered positive while samples showing no $\mathrm{Ct}$ were considered as negative. Qualitative (positive/negative) responses were recorded and results were analyzed based on threshold cycle $(\mathrm{Ct})$ values (Fig. 1). All the animals included in group $\mathrm{A}$ and $\mathrm{B}$ showed positive results for CSFV genomic RNA while samples from group $C$ were found negative for CSFV by qRT-PCR.

\section{Screening of samples for pig anti-CSFV antibody}

Samples included for the cytokine expression study were screened for presence of anti-CSFV antibodies using CSFV antibody test kit. The samples were considered positive at a calculated blocking percentage of $\geq 40 \%$ and negative at a blocking percentage $\leq 30 \%$. Serum from group A pigs showed a blocking percentage of 60-70\% (antibody titre of above 1:80), while serum from group $\mathrm{B}$ and $\mathrm{C}$ animals was negative for presence of anti-CSFV antibody.

Relative quantification of cytokine expression using quantitative real-time PCR ( $q R T-P C R$ )

The differential gene expression level for cytokine genes were normalized to the endogenous $\beta$-actin and were expressed as $2^{-\Delta \Delta C t}$ (fold change) relative to control. No significant differences of $\beta$-actin expression were found in infected and healthy control groups. The melting curve analysis performed after the completion of PCR confirmed the Tm (melting temperature) of amplified template. The amplification from the specific products of IL-6, IL-10, IFN- $\gamma$, TNF- $\alpha$ and $\beta$-actin were displayed with a $\mathrm{Tm}$ of $77.5^{\circ} \mathrm{C}, 79.9^{\circ} \mathrm{C}$, $74.1^{\circ} \mathrm{C}, 82.7^{\circ} \mathrm{C}$ and $85.7^{\circ} \mathrm{C}$, respectively.

RQ $\left(2^{-\triangle \Delta C T}\right)$ was the fold change in cytokine gene expression of groups A and B compared to the control group (unvaccinated-uninfected) and the control group was the calibrator with RQ value of 1 . All data were reported as the mean \pm standard deviation (SD) of RQ results and the error bars represented the SD. The group A showed maximum upregulation for IFN- $\gamma(\mathrm{RQ}=50.05 \pm 5.80)$ followed by IL-10 (RQ = 15.28 \pm 1.95$)$, TNF- $\alpha(R Q=13.95 \pm 2.56)$ and IL-6 $(R Q=4.53 \pm 0.92)$. In the unvaccinated-infected animals (group B), compared to the control group, the expression level of IFN- $\gamma(\mathrm{RQ}=1.20 \pm 0.07)$ remained unchanged, however, upregulation in IL-10, TNF- $\alpha$, and IL-6 expression levels were observed; expression level of IL-10 was found to be highly upregulated ( $\mathrm{RQ}=63.06 \pm 3.61$ ) followed by TNF- $\alpha(\mathrm{RQ}=40.10 \pm 2.61)$ and IL-6 $(\mathrm{RQ}=17.18 \pm 1.09)$. Significantly higher TNF- $\alpha$, IL-10, and IL-6 expression level were found in group B compared to group A, the difference being statistically significant $(p=0.001)$. However, the expression of IFN- $\gamma$ was significantly higher in group A compared to group $B(p=0.001)$. Differential modulation in cytokine expression pattern observed between group $\mathrm{A}$ and B is depicted in Fig. 2.

\section{Measurement of cytokine concentration by ELISA}

The cytokine (IL-6, IL-10, IFN- $\gamma$ and TNF- $\alpha$ ) concentrations (mean \pm SD) in $\mathrm{pg} / \mathrm{ml}$ for all the investigated groups are shown in Fig. 3. Alterations in plasma levels 


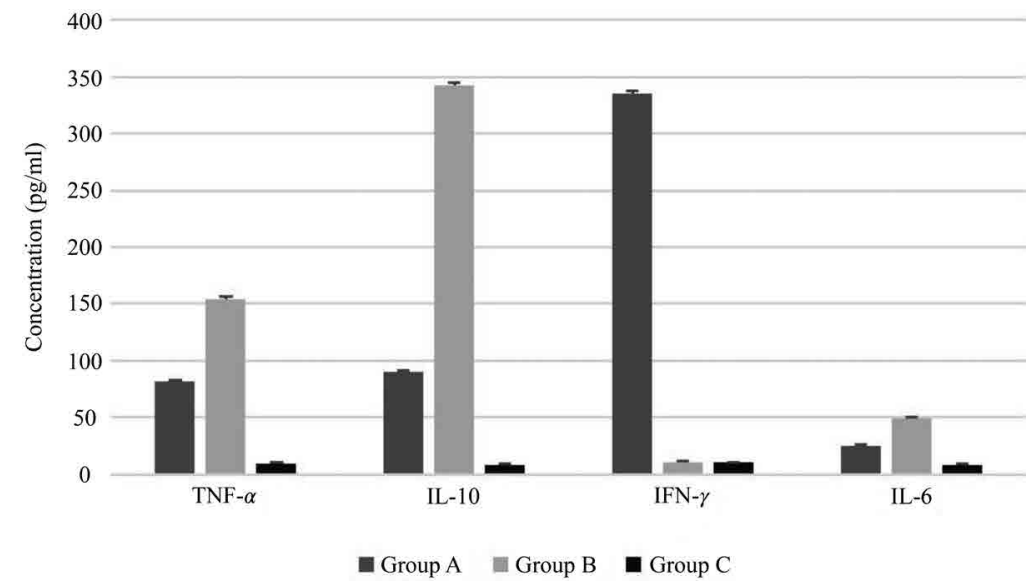

Fig. 3

Bar diagram representing the concentration of TNF- $\alpha$, IL-10, IFN- $\gamma$ and IL- 6 cytokines (pg/ml)

Concentrations of cytokines in group A (vaccinated-infected), group B (unvaccinated-infected) and group C (healthy controls). All data were reported as the mean $\pm \mathrm{SD}$ and the error bars represent the SD.

of pro-inflammatory markers TNF- $\alpha$, IL-6 and IFN $\gamma$, and anti-inflammatory marker IL-10 was evaluated by ELISA between group $\mathrm{A}$ and $\mathrm{B}$ and compared with the control group. The plasma concentration for IL-6, IL-10, IFN- $\gamma$ and TNF- $\alpha$ in control group (group C) was found to be $8.1 \pm 0.92 \mathrm{pg} / \mathrm{ml}, 7.8 \pm 1.9 \mathrm{pg} / \mathrm{ml}, 9.8 \pm 1.75 \mathrm{pg} / \mathrm{ml}$ and $9.1 \pm 1.56$ $\mathrm{pg} / \mathrm{ml}$, respectively. Group A animals showed maximum plasma concentration for IFN- $\gamma(335 \pm 2.1 \mathrm{pg} / \mathrm{ml})$ followed by IL-10 $(90 \pm 1.45 \mathrm{pg} / \mathrm{ml})$ and TNF- $\alpha(81 \pm 1.5 \mathrm{pg} / \mathrm{ml})$; IL-6 was found to have the least concentration $(25 \pm 1.43 \mathrm{pg} / \mathrm{ml})$ in plasma. However, in group B the concentration of IFN- $\gamma$ $(9.8 \pm 2.13)$ remained unchanged compared to the control group; highest plasma concentration was recorded for IL-10 $(343 \pm 2.02 \mathrm{pg} / \mathrm{ml})$ followed by TNF- $\alpha(154 \pm 2.1 \mathrm{pg} / \mathrm{ml})$ and IL-6 $(49 \pm 1.09 \mathrm{pg} / \mathrm{ml})$.

\section{Discussion}

The key point to design antiviral strategy against CSFV infection is to understand the interaction between virus and porcine immune cells and their immunomodulatory role in viral pathogenesis. The present study was carried out to evaluate the responses of TNF- $\alpha$, IL-6, IFN- $\gamma$ and IL-10 in the CSFV infected pigs under field conditions in order to understand the contribution of these responses in protection and its pathology. TNF- $\alpha$ and IL- 6 serve as inflammatory cytokines which are the important cause of tissue damage. IFN- $\gamma$, released by antigen-active T cells, plays an important role in immune regulation and IL-10 is an immunosuppressive cytokine secreted by wide variety of cells during the immune response. A herd of pigs were attended from an outbreak. This study focused on the initial stage of infection
( $<1$ week post infection), which largely predetermines the course and outcome of the disease.

Most of the investigatory studies for cytokine profile measurements are exclusively performed on isolated, purified cells, thus excluding other important blood elements which might take part in the immune response. For proper maintenance of cell viability and regular cytokine secretion, interactions between all cellular components are necessary (Hodge et al., 2000). The advantage WBA is that it keeps cells and plasma constituents similar to the in vivo environment in comparison to PBMC separation where those components of the blood are removed.

Antibody titre above 1:80 was recorded in serum collected from group A pigs. Absence of anti-CSF antibody in group B might be correlated with the fact that the animals had no history of vaccination against CSF, moreover, blood collection from the affected animals was done within 1 week of showing clinical symptoms. Higher antibody titre might have provided better protection to the group A animals. However, the correlation of antibody titres and cytokine patterns induced by vaccines could give a clear picture to reliably interpret the efficacy of vaccines with protective immunity. Neutralising antibodies detected $2-3$ weeks post vaccination by $\mathrm{C}$-strain is a major protective entity in the CSFV infected animals (Terpstra et al., 1990). However, it has been shown that in the absence of humoral immunity, $\mathrm{T}$ cell specific IFN- $\gamma$ responses that are detected 7 days postvaccination might mediate protection to the ailing animals (Suradhat et al., 2001, 2005).

Our result showed differential modulation of cytokine expression in group A and B animals. It was observed that in the recovered pigs, vaccination attenuated the effects induced by CSFV infection on the production of IL-10, TNF- $\alpha$ 
and IL-6. In accordance with the present findings, previous studies (Renson et al., 2013) have supported the fact that the production of IL-10, TNF- $\alpha$ and IL- 6 is related to CSFV pathogeny. Our report also corroborates with the findings that vaccination with the $\mathrm{C}$-strain vaccine did not increase the expression levels of TNF- $\alpha$ thereby avoiding the damage caused by inflammation (Xu et al., 2018).

Presumably, the high expression of immunosuppressive IL-10 in clinically affected pigs might be responsible for the reduced expression of IFN- $\gamma$, which in turn may prolong viral replication in pigs. Moreover, IL-10 and IFN- $\gamma$ might have an antagonizing effect as shown for the other viral disease conditions (Turner et al. 2002; Batista et al. 2004). High level of antibody titre and IFN- $\gamma$ expression in group A animals suggested their better protection. Our report corroborates with the earlier findings that immunosuppression and low antibody titre observed in infected pigs might be due to interference from maternal immunity and inappropriate vaccination (Suradhat and Damrongwatanapokin, 2003). Since CSFV is endemic in North East India, irregular vaccination and improper serological monitoring might be the reasons for vaccination failure to confer protection. Therefore, in order to prevent CSFV infection within endemic areas, routine serological surveys and strict biosecurity on farms should be maintained.

Our results show significant modulation in IL-6 gene expression between the group A and B pigs. IL-6 plays a crucial role in modulating the immune response and in inducing apoptosis during viral infection (Luster et al., 1999). Higher levels of IL-6 expression in swine blood upon infection of virulent CSFV strains suggests its significance (Choi et al., 2004; Sanchez-Cordon et al., 2005; Borca et al., 2008). Previous studies have demonstrated the involvement of TNF- $\alpha$ and, to a lesser extent, IL- 6 in the pathogenesis of lymphocytopenia and thrombocytopenia during CSFV infection (Sanchez-Cordon et al., 2005). There are reports that indicated that the overexpression of IL-6 might not induce obvious inflammatory damages in the vaccinated pigs; however, it plays an important role in immune regulation after vaccination with the C-strain vaccine (Xu et al., 2018).

Significantly higher IL-10 expression level, observed in group $\mathrm{B}(\mathrm{p}=0.001)$ compared to the group A pigs, could be the strategy used by the CSFV to evade the host's immune responses. IL-10 is known to inhibit the activity of Th1 and NK cells thereby, facilitating immunosuppression and viral persistence during CSFV infection (Blackburn and Wherry, 2007; Couper et al., 2008). The increased level of IL-10 in group B pigs might play a role in immunosuppression observed during the course of CSFV infection as suggested earlier (Suradhat et al., 2005; Jamin et al., 2008).

In accordance with the present findings, a study confirmed higher expression of IL-10 in sows and piglets in case of combined infection with porcine circovirus 2 (PCV2) and
CSFV attributing the probable reason to the immunosuppressive nature of both the viruses (Mukherjee et al., 2017).

The higher expression of IFN- $\gamma$ in group A animals as compared to group $B(p=0.001)$ suggests significance of IFN- $\gamma$ in controlling CSFV replication in infected animals. Previous studies have reported that the induction of IFN- $\gamma$ producing $\mathrm{T}$ cells in vaccinated animals is triggered by successful vaccination (Tarradas et al., 2010). Moreover, significantly higher numbers of IFN- $\gamma$ positive lymphocytes were reported in pigs inoculated with the Alfort187 strain of CSFV (Sanchez-Cordon et al., 2005a). For the immunized animals, infection activates a rapid and high-level IFN- $\gamma$ response, which provides protection to immunized animals at least until the emergence of neutralizing antibody (Xu et al., 2018). Our results strengthen the role of IFN- $\gamma$ or cell mediated immunity in eliciting the protection against CSFV infection in pigs.

TNF- $\alpha$ is known to induce apoptosis in several cell populations (Hernandez-Casellez and Stutman, 1993; Saldeen, 2000) which might be responsible for lymphoid depletion and immunosuppression in several viral diseases (Ohno et al., 1993; Razvi and Welsh, 1993). Our results showed enhanced expression of TNF-a following CSFV infection ( $p=0.001)$ in group B animals. TNF- $\alpha$ is shown to modulate the immune responses during CSFV infection (von Rosen et al., 2013) and might contribute to lower lymphocyte level seen in CSFV-infected pigs (Choi et al., 2004). These findings were supported by the earlier report citing presence of significant levels of TNF- $\alpha$ in peripheral blood leukocytes from animals infected with CSFV (Graham et al., 2009). In addition, positive correlation has been observed between expressions of TNF- $\alpha$ and cells showing signs of CSFV infection, suggesting its importance during infection (Sanchez-Cordon et al., 2005). The high levels of cytokines might induce apoptosis and/or impair DC maturation and T cell priming, which in turn, could play a role in disrupting immune system cells (Jamin et al., 2008).

Advanced techniques like microarray analysis can describe changes in levels of expression of a large number of genes at different time points following infection. Previous studies have implemented microarray analysis to assess changes in patterns of gene expression in peripheral blood-derived swine macrophages following infection by CSFV (Zixue et al., 2009; Gladue et al., 2010). Sophisticated mechanisms of CSFV infection can be studied by microarray analysis to understand the expression changes of numerous genes involved in immune and inflammatory responses and in the apoptosis process.

The present study was undertaken in the early clinical stage of CSFV infection highlighting the cytokine mediated immunobiology. Our study clearly showed that the expression of IL-10 during early CSFV infection is detrimental to the protective response. The overexpression of IL-10 in the 
clinically affected pigs clearly correlates with the reduced expression of the cytokine IFN- $\gamma$. This suggests that IL-10 is an active down-regulator of protective responses in the CSFV infected pigs. IFN- $\gamma$ is known to induce virus-specific T-lymphocyte response and is related to cytotoxic T lymphocyte activity, which could be identified as early as 1 week post-vaccination. In the absence of neutralizing antibodies, such as 1-3 weeks after vaccination, cellular immunity in the form of IFN- $\gamma$ can provide protective immunity to pigs against CSFV (Terpstra and Wensvoort, 1988; Suradhat et al., 2001; Dewulf et al., 2004). The present work demonstrates that IFN- $\gamma$ is particularly evident in the animals that recovered after CSFV infection.

In summary, our study showed the role of porcine cytokines, IL-6, IL-10, IFN- $\gamma$ and TNF- $\alpha$ in the initial stages of CSFV infection in pigs. These findings could be of importance for future vaccine design, considering the immunology of CSFV. The kinetics of the cytokine response suggests that IL-10 mediated immune suppression might play an important role in the pathogenesis of CSFV. High IFN $-\gamma$ production as part of a Th1-driven immune response might be associated with a more favourable outcome and this effect can be attributed to the monocyte-macrophage-activating capacity of IFN- $\gamma$. We believe that the WBA technique mimics the porcine blood conditions and it is inexpensive and easy to perform, being a valuable tool for studying porcine cytokine profiles. A critical limitation of the current study was the sample size. However, the findings of this field-supported study will help us to understand the immune biology of CSFV infection in infected pigs. In a forthcoming perspective for development of new CSFV vaccine, it is needed to identify antigens inducing balanced Th1 responses.

Acknowledgment. The authors would like to thank the Department of Biotechnology, Government of India, for providing financial help to carry out the research under the project entitled, 'DBT Network project on Classical Swine Fever with special reference to north-eastern region' and subproject entitled, 'Classical swine fever: surveillance and monitoring in some north-eastern States and Establishment of National Classical Swine Fever Virus Repository' and the State Biotech Hub, College of Veterinary Science, Khanapara, Assam, India, for providing necessary laboratory facilities. We are thankful to Dr. Monika Koul for proof reading the manuscript. Generous help rendered by Dr. Sujoy Bose, Assistant Professor, Department of Biotechnology, Gauhati University in performing statistical analysis is duly acknowledged.

\section{References}

Abbas AK, Murphy KM, Sher A (1996): Functional diversity of helper T lymphocytes. Nature 383, 787-793. https://doi. org/10.1038/383787a 0
Arzt J, White WR, Thomsen BV, Brown CC (2010): Agricultural diseases on the move early in the third millennium. Vet. Pathol. 47, 15-27. https://doi.org/10.1177/0300985809354350

Barman NN, Gupt RS, Bora DP, Kataria RS, Tiwari AK, Roychoudhury P (2010): Molecular characterization of classical swine fever virus involved in the outbreak in Mizoram. Ind. J. Virol. 21, 76-81. https://doi.org/10.1007/s13337010-0006-Z

Barman NN, Nath AA, Hazarika MP, Barman B, Thakuria D (2003): Outbreak of classical swine fever in regularly vaccinated pig herd. Ind. J. of Comp. Microbiol. Immunol. Infect. Dis. 24, 89-90.

Batista L, Pijoan C, Dee S, Olin M, Molitor T, Joo H S, Xiao Z, Murtaugh M (2004): Virological and immunological responses to porcine reproductive and respiratory syndrome virus in a large population of gilts. Can. J. Vet. Res. 68, 267-273.

Blackburn SD, Wherry EJ (2007): IL-10, T cell exhaustion and viral persistence. Trends Microbiol. 15, 143-146. https://doi. org/10.1016/j.tim.2007.02.006

Borca MV, Gudmundsdottir I, Fernandez-Sainz IJ, Holinka LG, Risatti GR (2008): Patterns of cellular gene expression in swine macrophages infected with highly virulent classical swine fever virus strain Brescia. Virus Res. 138, 89-96. https://doi.org/10.1016/j.virusres.2008.08.009

Choi C, Hwang KK, Chae C (2004): Classical swine fever virus induces tumor necrosis factor-alpha and lymphocyte apoptosis. Arch. Virol. 149, 875-889. https://doi.org/10.1007/ s00705-003-0275-6

Couper KN, Blount DG, Riley EM (2008): IL-10: the master regulator of immunity to infection. J. Immunol. 180, 5771-5777. https://doi.org/10.4049/jimmunol.180.9.5771

de las Mulas JM, Ruiz-Villamor E, Donoso S, Quezada M, Lecocq C, Sierra MA (1997): Immunohistochemical detection of hog cholera viral glycoprotein 55 in paraffin embedded tissues. J. Vet. Diagn. Invest. 9, 10-16. https://doi. org/10.1177/104063879700900103

Dewulf J, Laevens H, Koenen F, Mintiens K, de Kruif A (2004): Efficacy of E2- sub-unit marker and C-strain vaccines in reducing horizontal transmission of classical swine fever virus in weaner pigs. Prev. Vet. Med. 65, 121-133. https:// doi.org/10.1016/j.prevetmed.2004.05.010

Doherty PC, Allan W, Eichelberger M (1992): Roles of ab and gd $\mathrm{T}$ cell subsets in viral immunity. Annu. Rev. Immunol. 10, 123-151. https://doi.org/10.1146/annurev. iy.10.040192.001011

Francki RIB, Faquet CM, Knudson DL, Brown F (1991): Fifth report of the international committee on taxonomy of viruses. Arch. Virol. 2, 223-233.

Galindo RC, Ayllón N, Smrdel KS, Boadella M, Beltrán-Beck B, Mazariegos M et al. (2012): Gene expression profile suggests that pigs (Sus scrofa) are susceptible to Anaplasma phagocytophilum but control infection. Parasites \& Vectors 5, 181. https://doi.org/10.1186/1756-3305-5-181

Ganges L, Barrera M, Nunez JI, Blanco I, Frias MT, Rodriguez F, Sobrino $F$ (2005): A DNA vaccine expressing the E2 protein of classical swine fever virus elicits $\mathrm{T}$ cell responses that can prime for rapid antibody production and confer total 
protection upon viral challenge. Vaccine 23, 3741-3752. https://doi.org/10.1016/j.vaccine.2005.01.153

Ganges L, Nunez JI, Sobrino F, Borrego B, Fernandez-Borges N, Frias-Lepoureau MT, Rodriguez F (2008): Recent advances in the development of recombinant vaccines against classical swine fever virus: cellular responses also play a role in protection. Vet. J. 177, 169-177. https://doi. org/10.1016/j.tvjl.2007.01.030

Gladue D, Zhu J, Holinka L, Fernandez Sainz I, Carrillo C, Prarat M, O'Donnell V, Borca M (2010): Patterns of gene expression in swine macrophages infected with classical swine fever virus detected by microarray. Virus Res. 151, 10-18. https://doi.org/10.1016/j.virusres.2010.03.007

Graham SP, Everett HE, Haines FJ, Johns HL, Sosan OA, Salguero FJ, Clifford DJ, Steinbach F, Drew TW, Crooke HR (2012): Challenge of pigs with classical swine fever viruses after $\mathrm{C}$-strain vaccination reveals remarkably rapid protection and insights into early immunity. PLoS One 7, e29310. https://doi.org/10.1371/journal.pone.0029310

Graham SP, Everett HE, Johns HL, Haines FJ, Rocca SA, Khatri M, Drew T, Crooke HR (2009): Characterisation of virusspecific peripheral blood cell cytokine responses following vaccination or infection with classical swine fever viruses. Vet. Microbiol. 142, 34-40. https://doi.org/10.1016/j. vetmic.2009.09.040

Hernandez-Casellez T, Stutman O (1993): Immune function of TNF. I. TNF induces apoptosis in mouse thymocytes and can also stimulate or inhibit IL-6-induced proliferation depending on the concentration of mitogenic costimulation. J. Immunol. 151, 3999-4012.

Hodge G, Hodge S, Han P (2000): Increased levels of apoptosis of leukocyte subsets in cultured PBMCs compared to whole blood as shown by Annexin $\mathrm{V}$ binding: relevance to cytokine production. Cytokine 12, 1763-1768. https:// doi.org/10.1006/cyto. 2000.0790

Hoffmann B, Beer M, Schelp C, Schirrmeier H, Depner K (2005): Validation of a real-time RT-PCR assay for sensitive and specific detection of classical swine fever. J. Virol. Methods 130, 36-45. https://doi.org/10.1016/j.jviromet.2005.05.030

Hulst MM, Westra DF, Wensvoort G, Moormann RJ (1993): Glycoprotein $\mathrm{E} 1$ of hog cholera virus expressed in insect cells protects swine from hog cholera. J. Virol. 67, 5435-5442.

Jamin A, Gorin S, Cariolet R, Le Potier MF, Kuntz-Simon G (2008): Classical swine fever virus induces activation of plasmacytoid and conventional dendritic cells in tonsil, blood, and spleen of infected pigs. Vet. Res. 39, 7. https://doi. org/10.1051/vetres:2007045

Kuleshova LL, Shaw JM, Trounson AO (2001): Studies on replacing most of the penetrating cryoprotectant by polymers for embryo cryopreservation. Cryobiology 43, 21-31. https:// doi.org/10.1006/cryo.2001.2335

Lagrelius M, Jones P, Franck K, Gaines H (2006): Cytokine detection by multiplex technology useful for assessing antigen specific cytokine profiles and kinetics in whole blood cultured up to seven days. Cytokine 33, 156-165. https:// doi.org/10.1016/j.cyto.2006.01.005
Li M, Wang YF, Wang Y, Gao H, Li N, Sun Y, Liang BB, Qiu HJ (2009): Immune responses induced by a BacMam virus expressing the E2 protein of classical swine fever virus in mice. Immunol. Lett. 125,145-150 https://doi. org/10.1016/j.imlet.2009.07.001

Livak KJ, Schmittgen TD (2001): Analysis of relative gene expression data using real-time quantitative PCR and the $2-\Delta \Delta$ CT method. Methods 25, 402-408. https://doi. org/10.1006/meth.2001.1262

Luster MI, Simeonova PP, Galluci R, Mathenson J (1999): Tumor necrosis factor alpha and toxicology. Crit. Rev. in Toxicol. 29, 491-511. https://doi.org/10.1080/10408449991349258

Mukherjee P, Dewry R, Karam A, Singh U, Chakraborty AK, Das S, Puro K, Sanjukta R, Ghatak S, Shakuntala I, Laha RG, Ngachan SV, Sen A, Sharma I (2017): Comparative enumeration of cytokine immune response in PBMC's of sows and piglets infected with porcine circovirus and classical swine fever virus. Indian J. Comp. Microbiol. Immunol. Infect. Dis. 38, 136-145. https://doi. org/10.5958/0974-0147.2017.00022.8

Mu-oz-González S, Pérez-Simó M, Colom-Cadena A, Cabezón O, Bohórquez JA, Rosell R, et al. (2016): Classical swine fever virus vs. classical swine fever virus: The superinfection exclusion phenomenon in experimentally infected wild boar. PLoS ONE 11, e0149469. https://doi.org/10.1371/ journal.pone. 0149469

Narita M, Kawashima K, Kimura K, Mikami O, Shibahara T, Yamada S, Sakoda Y (2000): Comparative immunohistopathology in pigs infected with highly virulent or less virulent strains of hog cholera virus. Vet. Pathol. 37, 402-408. https://doi.org/10.1354/vp.37-5-402

Ohno K, Nakato Y, Matsumoto Y, Waatari T, Goitsuka R, Nakayama H, Tsujimoto H, Hasegawa A (1993): Apoptosis induced by tumor necrosis factor in cells chronically infected with feline immunodeficiency virus. J. Virol. 67, 2429-2433.

OIE Disease Information. 15th July 2005, 18, 201.

Paton DJ, Greiser-Wilke I (2003): Classical swine fever-an update. Res. Vet. Sci. 75, 169-178. https://doi.org/10.1016/S0034$\underline{5288(03) 00076-6}$

Pauly T, Elbers K, Konig M, Lengsfeld T, Saalmuller A, Thiel H] (1995): Classical swine fever virus-specific cytotoxic T lymphocytes and identification of a T cell epitope. J. Gen. Virol. 76, 3039-3049. https://doi.org/10.1099/0022-131776-12-3039

Rahman H, Chakraborty A, Deka P, Narayan G, Prager R (2001): An outbreak of Salmonella enteritidis infection in pygmy hogs (Sus salvanius). Trop. Anim. Hlth. Prod. 33, 95-102. https://doi.org/10.1023/A:1005229412814

Razvi ES, Welsh RM (1993): Programmed cell death of T-lymphocytes during acute viral infection. A mechanism for virus induced immune deficiency. J. Virol. 67, 5754-5765.

Renson P, Le Dimna M, Keranflech A, Cariolet R, Koenen F, Le Potier MF (2013): CP7_E2alf oral vaccination confers partial protection against early classical swine fever virus challenge and interferes with pathogeny-related cytokine responses. Vet. Res. 44, 9. https://doi.org/10.1186/12979716-44-9 
Rumenapf T, Stark R, Meyers G, Thiel HJ (1991): Structural proteins of hog cholera virus expressed by vaccinia virus: further characterization and induction of protective immunity. J. Virol. 65, 589-597.

Saldeen, J (2000): Cytokines induce both necrosis and apoptosis via a common bcl-2-inhibitable pathway in rat insulin producing cell. Endocrinol. 141, 2003-2010. https://doi. org/10.1210/endo.141.6.7523

Sanchez-Cordon PJ, Nunez A, Salguero FJ, Carrasco L, GomezVillamandos JC (2005a): Evolution of T lymphocytes and cytokine expression in classical swine fever (CSF) virus infection. J. Comp. Pathol. 132, 249-260. https:// doi.org/10.1016/j.jcpa.2004.10.002

Sanchez-Cordon PJ, Nunez A, Salguero FJ, Pedrera M, Fernandez de Marco M, Gomez-Villamandos JC, Marco M (2005): Lymphocyte apoptosis and thrombocytopenia in spleen during classical swine fever: role of macrophages and cytokines. Vet. Pathol. 42, 477-488. https://doi.org/10.1354/ vp. $42-4-477$

Sarma DK, Mishra N, Rajkumar K, Sarma S, Singh NK (2008): Isolation and characterization of classical swine fever virus from pigs in Assam. Ind. J. Anim. Sci. 78, 37-39.

Sarma DK, Mishra N, Vilcek S, Rajukumar K, Behera SP, Nema RK, Dubey P, Dubey SC (2011): Phylogenetic analysis of recent classical swine fever virus (CSFV) isolates from Assam. India Comp. Immunol. Microbiol. Infect. Dis. 34, 11-15. https://doi.org/10.1016/j.cimid.2009.09.005

Sarma PC, Sarma DK (1998): Isolation and identification of a virulent strain of hog cholera virus from field outbreaks. Ind. J. Virol. 14, 41-42.

Sato M, Mikami O, Kobayashim M, Nakajima Y (2000): Apoptosis in the lymphatic organs of piglets inoculated with classical swine fever virus. Vet. Microbiol. 75, 1-9. https://doi. org/10.1016/S0378-1135(00)00198-X

Silberer J, Ihorst G, Kopp MV (2008): Cytokine levels in supernatants of whole blood and mononuclear cell cultures in adults and neonates reveal significant differences with respect to interleukin-13 and interferon-gamma. Pediatr. Allergy Immunol. 19, 140-147. https://doi.org/10.1111/ j.1399-3038.2007.00605.x

Summerfield A, Rziha HJ, Saalmuller A (1996): Functional characterization of porcine CD4+CD8+ extrathymic T lymphocytes. Cell Immunol. 168, 291-296. https://doi. org/10.1006/cimm.1996.0078

Summerfield A, Zingle K, Inumaru S, McCullough KC (2001): Induction of apoptosis in bone marrow neutrophil-lineage cells by classical swine fever virus. J. Gen. Virol. 82, 13091318. https://doi.org/10.1099/0022-1317-82-6-1309

Suradhat S, Damrongwatanapokin S (2003): The influence of maternal immunity on the efficacy of a classical swine fever vaccine against classical swine fever virus, genogroup 2.2, infection. Vet. Microbiol. 92, 187-194. https://doi. org/10.1016/S0378-1135(02)00357-7
Suradhat S, Intrakamhaeng M, Damrongwatanapokin S (2001): The correlation of virus-specific interferon-gamma production and protection against classical swine fever virus infection. Vet. Immunol. Immunopathol. 83, 177-189. https://doi.org/10.1016/S0165-2427(01)00389-0

Suradhat S, Sada W, Buranapraditkun S, Damrongwatanapokin S (2005): The kinetics of cytokine production and CD25 expression by porcine lymphocyte subpopulations following exposure to classical swine fever virus (CSFV). Vet. Immunol. Immunopathol. 106, 197-208. https://doi. org/10.1016/j.vetimm.2005.02.017

Tarradas J, Argilaguet JM, Rosell R, Nofrarias M, Crisci E, Cordoba L, Perez-Martin E, Diaz I, Rodriguez F, Domingo M, Montoya M, Ganges L (2010): Interferon-gamma induction correlates with protection by DNA vaccine expressing E2 glycoprotein against classical swine fever virus infection in domestic pigs. Vet. Microbiol. 142, 51-58. https://doi. org/10.1016/j.vetmic.2009.09.043

Terpstra C, Wensvoort G (1988): The protective value of vaccineinduced neutralising antibody titres in swine fever. Vet. Microbiol. 16, 123-128. https://doi.org/10.1016/03781135(88)90036-3

Terpstra C, Woortmeyer R, Barteling SJ (1990): Development and properties of a cell culture produced vaccine for hog cholera based on the Chinese strain. Dtsch. Tierarztl. Wochenschr. 97, 77-79.

Turner J, Gonzalez-Juarrero M, Ellis DL, Basaraba RJ, Kipnis A, Orme IM, Cooper AM (2002): In vivo IL-10 production reactivates chronic pulmonary tuberculosis in C57BL/6 mice. J. Immunol. 169, 6343-6351. https://doi. org/10.4049/jimmunol.169.11.6343

von Rosen T, Lohse L, Nielsen J, Uttenthal A (2013): Classical swine fever virus infection modulates serum levels of INF-alpha, IL-8 and TNF-alpha in 6-month-old pigs. Res. Vet. Sci. 95, 1262-1267. https://doi.org/10.1016/j.rvsc.2013.09.011

Xu L, Fan XZ, Zhao QZ, Zhang ZX, Chen K, Ning YB, Zhang QY, Zou XQ, Zhu YY, Li C, Zhang YJ, Wang Q (2018): Effects of vaccination with the $C$-Strain vaccine on immune cells and cytokines of pigs against classical swine fever virus. Viral Immunol. 31, 34-39. https://doi.org/10.1089/ vim.2017.0010

Zheng L, Fisher G, Miller RE, Peschon J, Lynch DH, Lenardo MJ (1995): Induction of apoptosis in mature T cells by tumor necrosis factor. Nature 377, 348-351. https://doi. org/10.1038/377348a0

Zixue Shi, Jinfu Sun, Huancheng Guo, Changchun Tu (2009): Genomic expression profiling of peripheral blood leukocytes of pigs infected with highly virulent classical swine fever virus strain Shimen. J. Gen. Virol. 90, 1670-1680. https://doi.org/10.1099/vir.0.009415-0 